\title{
Soil Seed Bank Dynamics in Tithonia diversifolia Dominated Fallowland Vegetation in Ile-Ife Area of Southwestern Nigeria
}

\author{
Samson Olajide OKE, Olaniran Temitope OLADIPO, Charlottee Chibuzor \\ NDIRIBE, Damilare Stephen AKINYEMI, Olubukola Modupe OJO
}

Obafemi Awolowo University, Department of Botany, Ile-Ife,Nigeria; soke@oauife.edu.ng

\begin{abstract}
The soil seedbank of Tithonia diversifolia, an invasive species which dominates open waste fallowland vegetation was studied. Two different roadside sites which vary in extent of open waste land were selected.The species composition of the established vegetation was assessed in the two diferent sites. Twenty top soil samples were collected at five different distances $(15 \mathrm{~cm}, 30 \mathrm{~cm}, 45 \mathrm{~cm}, 60 \mathrm{~cm}$, and $75 \mathrm{~cm}$ ) inwards away from each main road in dry and rainy seasons and the seed bank composition was determined by greenhouse germination over a 6 month period. The similarity between the composition of the seed bank flora and that of the established vegetation was low. The least and the highest emerged seedlings density was recorded in the 15 metres and 75 metres respectively inwards away from the main road in both seasons. The results of the seedlings emergence is a reflection of the extent of open waste land dominated by the invasive species due to human disturbance (road construction) on both sites. Overall results suggest that the emergence of the species from the soil seed bank may be due to the impact of the invasive species Tithonia diversifolia on other plant species in the study environment.
\end{abstract}

Keywords: Invasive species, fallowland, seedling emergence, soil seed bank, Tithonia diversifolia

\section{Introduction}

The introduction of plant species into a new environment, deliberately or otherwise, can have many unanticipated ecological effects (Howard and Harteminkl, 2000). These introduced species, otherwise called invasive species, can have devastating effects on the ecosystem quality and functioning as they often time out-compete indigenous or native species, thereby leading to the extinction or disappearance of endemic species (Lorence and Suesman, 1986). The threat to biodiversity due to invasive alien species is considered second, only to that of habitat destruction. Invasive species cause loss of biodiversity including species extinction, and changes in hydrology and ecosystem function. Thus, invasive species are a serious threat to conservation and sustainable use of biodiversity with undesirable impacts on the services provided by the ecosystem (Raghubanshi et al., 2005). Invasive species/plants such as Tithonia diversifolia have been shown to impede both ecological and conservation studies (Adebowale and Olorode, 2005). The mechanism by which invasive species affect native communities may include competition, altered ecosystem processes, or other pathways like allelopathy or phytotoxicity (Samuel et al., 2005). Invasive species have been reported to affect seedlings emergence of native species to varying degrees (Samuel et al., 2005). Similarly, Samuel et al. (2005) reported that extracts from parts of certain invasive species affected seedling emergence time, leaf biomass of native tree seedlings to varying degrees in the native species.

In Nigeria, especially in the lowland rainforest as well as in other habitats, these exotic/alien species, especially Tithonia diversifolia, now dominate a sizeable portion of the secondary fallow vegetation. Invasive species cause a reduction in native biodiversity through negative effect on the recruitment and persistence of native plant species $(\mathrm{Pa}-$ gad and Browne, 2008). They tend to be highly successful as judged, in part by their ability to produce abundance of seeds, that may be a life long in the soil seed bank. The invasion of the tropical rainforest landscape of Nigeria by Tithonia diversifolia is generating a lot of concern regarding their aggressive growth rate, heavy seed production and allelopathy.

In this work we focuse our efforts on the role of Tithonia diversifolia in secondary fallowland vegetation dynamics and in potential of a community for restoration/regeneration from soil seed bank. The aim of this study is to determine the density and dynamics of germinable seeds in the soil seed bank of secondary fallowland of Tithonia diversifolia dominated environment in relation to season; to assess the relationship between the composition of the established vegetation and the seed bank; to determine the effect of extent of disturbed/fallowland due to human dis- 
30

turbance such as road construction colonised by Tithonia diversifolia on seedling emergence in the study sites.

\section{Materials and methods}

The study sites are the secondary fallowland vegetation (due to human disturbance by road construction) dominated by Tithonia diversifolia along Ife-Ibadan dual carriage way (070 29.919'N; $004026.871 \mathrm{E})$ and Ife-Ilesa single lane highway $\left(07031.866{ }^{\prime} \mathrm{N}\right.$; 004034.424 'E) in IleIfe area of Southwestern Nigeria. The study was carried out between 2006 and 2007 . The mean annual rainfall of $1400 \mathrm{~mm}$ (five year mean) has been reported for Ile-Ife (Oke and Isichei, 1997). The soils of the study sites have been classified as Iwo series (Smyth and Montgomery, 1962) while the vegetation is lowland rainforest. In both of the two study sites, soil samples were collected in two occassions, before and during rainy season, i.e. March and July 2006 respectively. Soil samples were taken using soil auger (diameter $8.5 \mathrm{~cm}$ ) at a depth of $0-15 \mathrm{~cm}$. The soil samples were randomly collected from distances, 15, 40, 45,60 and $75 \mathrm{~m}$, inward away from the roadside to the forest edge across the secondary fallowland vegetation. The soil samples were then packed, labelled and transfered to the laboratory at the Department of Botany, Obafemi Awolowo University, Ile-Ife, Nigeria where they were spread on the laboratory tables and air-dried.

The soil samples were set in containers for seeds germination under nursery conditions. Germinated seeds were observed, identified and counted daily, up to six months. Emerged seedlings were identified as trees/shrubs, herbs and grasses. The seedlings were removed after counting and identification, to facilitate further germination and counting. The identification followed Hutchinson and Dalziel (1954-72) flora of west tropical Africa. Unidentified seedlings that were required for correct identification were uprooted and transplanted into bigger pots until proper identification could be carried out at IFE Herbarium. Number of emerged seedlings was obtained in each site and season. The percentage contribution of each species to the soil seed bank was also determined seasonally. Similarity indices (based on Sorenson's index) was also used to compare the similarity in species composition (standing vegetation and seed bank) among the two study sites. A two way Analysis of Variance (ANOVA) was used to compare the soil seed bank density per site for the two seasons.

\section{Results}

\section{Species composition of the standing vegetation}

The standing vegetation species composition of the two study sites is presented in Tab. 1. Thirty-two (32) plant species belonging to 22 families were encountered in the standing vegetation in the two sites; the species were predominantly shrubs and herbaceous species. The list also re-
Tab. 1. Plant species composition of the standing vegetation of the study plots.

\begin{tabular}{llcc}
\hline \multicolumn{1}{c}{ Species } & \multicolumn{1}{c}{ Family } & Site 1 & Site 2 \\
Andropogon gayanus & Poacea & + & + \\
Aspilia helianthus & Asteracea & + & - \\
Bracharia deflexa & Poacea & + & + \\
Cassia hirsuata & Caesalpiniacea & + & - \\
Chromolaena odorata & Asteracea & + & - \\
Cnetis feruginea & Connaracea & - & + \\
Combretum platypterum & Combretacea & - & + \\
Deinbollia pinnata & Sapindacea & - & + \\
Desmodium scorpiurrus & Fabaceae & + & + \\
Euphorbia heterophylla & Euphorbiaceae & + & - \\
Euphorbia hirta & Euphorbiaceae & + & - \\
Ficus exasperata & Moraceae & - & + \\
Icacina trichantha & Icacinaceae & - & + \\
Indigofera pulcra & Papilionaceae & + & - \\
Ipomea involucrata & Convolvulaceae & - & + \\
\hline
\end{tabular}

veals the presence of nine (9) woody species (28.1\%), grass species $(9.4 \%)$ and twenty herbaceous species (62.5\%). A low level of similarity (40\%) exists between the standing vegetation of the two study sites, showed by using similarity analysis (Sorenson, 1948). The eight (8) common plant species in the standing vegetation at the two study sites are : Andropogon tectorum, Bracharia deflexa, Desmodium scorpiurus, Phyllantus amarus, Sida acuta, Spigellia anthelmia, Trema orietalis and Tithonia diversifolia.

\section{Species richness and density of soil seed bank.}

The species composition of the soil seed bank of the two study sites is presented in Tab. 2. In the study site no. 1 (Ife-Ibadan road), in the rainy season sampling, a total of 359 seedlings $\left(6328 \mathrm{seed} / \mathrm{m}^{2}\right)$ emerged in this study site, in all periods of the germination studies (Tab. 2). Twenty six (26) species emerged, containing only one woody species (Tremia orientalis). Tithonia diversifolia had the highest seedling density of 87 seedlings $\left(1533 \mathrm{seeds} / \mathrm{m}^{2}\right.$ ) respectivly $24.2 \%$ of the total seed density of the soil seed bank. Oldenlanda corymbosa had the second highest seedling density of 60 seedlings $\left(1057\right.$ seeds $/ \mathrm{m}^{2}$ ), or $16.7 \%$ of the total seed density of the soil seed bank. Eight (8) species namely Ageratum conyzoides, Ceratropteris cornuta, Diodia scandens, Ipomoea triloba, Mimosa pudica, Paulinia pinnata, Tremia orientalis and Urena lobata had only one seedling each $\left(18\right.$ seeds $\left./ \mathrm{m}^{2}\right)$ or $0.3 \%$, emerged from the seed bank; other species had intermediate values. There were two unidentified species encountered in this study site 1 .

In the dry season sampling 898 seedlings ( 15822 seeds/ $\mathrm{m}^{2}$ ) emerged in all the months of the germination studies. Twenty-seven (27) species emerged from this study site 1 and only two plant species were unidentified. Oldenlandia 
Tab. 2. Density of species (seedlings $/ \mathrm{cm}^{2}$ and seeds $/ \mathrm{m}^{2}$ ) that emerged from soil collection in the two study plots in both seasons (Rainy and Dry seasons)

\begin{tabular}{|c|c|c|c|c|c|c|c|c|c|c|c|c|c|}
\hline \multicolumn{8}{|c|}{ SITE 1} & \multicolumn{6}{|c|}{ SITE 2} \\
\hline \multirow{2}{*}{$S \times N$} & \multirow{2}{*}{ Species } & \multicolumn{3}{|c|}{ Rainy season } & \multicolumn{3}{|c|}{ Dry season } & \multicolumn{3}{|c|}{ Rainy season } & \multicolumn{3}{|c|}{ Dry season } \\
\hline & & $\mathrm{s} / \mathrm{cm}^{2}$ & $\mathrm{~s} / \mathrm{m}^{2}$ & \% C.S & $\mathrm{s} / \mathrm{cm}^{2}$ & $\mathrm{~s} / \mathrm{m}^{2}$ & \% C.S & $\mathrm{s} / \mathrm{cm}^{2}$ & $\mathrm{~s} / \mathrm{m}^{2}$ & \% C.S & $\mathrm{s} / \mathrm{cm}^{2}$ & $\mathrm{~s} / \mathrm{m}^{2}$ & \% C.S \\
\hline 1 & Ageratum conyzoides & 1 & 18 & 0.3 & 1 & 18 & 0.1 & 1 & 18 & 0.3 & 13 & 229 & 0.8 \\
\hline 2 & Andropogon gayanus & 5 & 88 & 1.4 & 5 & 88 & 0.6 & 5 & 88 & 1.6 & 11 & 194 & 0.7 \\
\hline 3 & Andropogon tectorum & 3 & 53 & 0.8 & - & - & - & 5 & 88 & 1.6 & - & - & - \\
\hline 4 & Aspilia belianthus & - & - & - & 2 & 35 & 0.2 & - & - & - & - & - & - \\
\hline 5 & Brachiraria deflexa & 34 & 599 & 9.5 & 187 & 3295 & 20.8 & 138 & 2432 & 44.4 & 429 & 7559 & 27.9 \\
\hline 6 & Celosia trygnia & 5 & 88 & 1.4 & 3 & 53 & 03 & - & - & - & - & - & - \\
\hline 7 & Ceraptopteris cornuta & 1 & 18 & 03 & 2 & 35 & 0.2 & - & - & - & 1 & 18 & 0.1 \\
\hline 8 & Chromolaena odorata & 22 & 388 & 6.1 & 17 & 300 & 1.9 & 42 & 740 & 13.5 & 388 & 6837 & 25.2 \\
\hline 9 & Desmodium scorparius & - & - & - & 7 & 123 & 0.8 & - & - & - & 8 & 141 & 0.5 \\
\hline 10 & Diodia scandens & 1 & 18 & 0.3 & 4 & 70 & 0.4 & 15 & 264 & 4.8 & 146 & 2573 & 9.5 \\
\hline 11 & Euphorbia heterophylla & 25 & 441 & 7.0 & 1 & 18 & 0.1 & & & & 3 & 53 & 0.2 \\
\hline 12 & Euphorbia birta & 4 & 70 & 1.1 & 5 & 88 & 0.6 & 1 & 18 & 0.3 & - & - & - \\
\hline 13 & Euphorbia hyssopifolia & - & - & - & 14 & 247 & 1.6 & - & - & - & - & - & - \\
\hline 14 & Ipomea triloba & 1 & 18 & 0.3 & - & - & - & - & - & - & - & - & - \\
\hline 15 & Ipomea involucrata & - & - & - & - & - & - & - & - & - & 1 & 18 & 0.1 \\
\hline 16 & Lantana camara & 10 & 176 & 2.8 & 3 & 53 & 0.3 & - & - & - & 24 & 423 & 1.6 \\
\hline 17 & Laportea aestuans & 8 & 141 & 2.2 & 4 & 70 & 0.4 & 1 & 18 & 0.3 & 1 & 18 & 0.1 \\
\hline 18 & Lindernia crisstacea & - & - & - & - & - & - & - & - & - & 13 & 229 & 0.8 \\
\hline 19 & Mimosapudica & 1 & 18 & 0.3 & 3 & 53 & 0.3 & - & - & - & - & - & - \\
\hline 20 & Oldenlandia corymbosa & 60 & 1057 & 16.7 & 276 & 4863 & 30.7 & 31 & 546 & 10.0 & 294 & 5181 & 19.1 \\
\hline 21 & Oxalis corniculata & - & - & - & - & - & - & - & - & - & 3 & 53 & 0.2 \\
\hline 22 & Paulinia pinnata & 1 & 18 & 0.3 & - & - & - & - & - & - & - & - & - \\
\hline 23 & Peperomia pellucida & 2 & 35 & 0.6 & 5 & 88 & 0.6 & 10 & 176 & 3.2 & - & - & - \\
\hline 24 & Perotis indica & - & - & - & 2 & 35 & 0.2 & - & - & - & - & - & - \\
\hline 25 & Phyllanthus amarus & 2 & 35 & 0.6 & 29 & 511 & 3.2 & 4 & 70 & 1.3 & 22 & 388 & 1.4 \\
\hline 26 & Physalis anguculata & - & - & - & 1 & 18 & 0.1 & 1 & 18 & 0.3 & - & - & - \\
\hline 27 & Portulaca oleracea & 7 & 123 & 2.0 & 13 & 229 & 1.4 & - & - & - & 6 & 106 & 0.4 \\
\hline 28 & Securinega virosa & - & - & - & - & - & - & 1 & 18 & 0.3 & - & - & - \\
\hline 29 & Sida veronicifolia & - & - & - & - & - & - & 1 & 18 & 0.3 & - & - & - \\
\hline 30 & Spigelia anthelmia & 5 & 88 & 1.4 & 18 & 317 & 2.0 & 10 & 176 & 3.2 & 127 & 2238 & 8.3 \\
\hline 31 & Talinum triangulare & 51 & 899 & 14.2 & 81 & 1427 & 9.0 & - & - & - & 7 & 123 & 8.3 \\
\hline 32 & Tithonia diversifolia & 87 & 1533 & 24.2 & 193 & 3401 & 21.4 & 24 & 423 & 7.7 & 25 & 441 & 1.6 \\
\hline 33 & Trianthema portulacastrum & - & - & - & 15 & 264 & 17 & - & - & - & - & - & - \\
\hline 34 & Trema orientalis & 1 & 18 & 0.3 & - & - & - & 2 & 35 & 0.6 & 1 & 18 & 0.1 \\
\hline 35 & Urena lobata & 1 & 18 & 0.3 & - & - & - & - & - & - & - & - & - \\
\hline 36 & Unidentified Y & 4 & 70 & 1.1 & 2 & 35 & 0.2 & 17 & 300 & 5.5 & 13 & 229 & 0.8 \\
\hline \multirow[t]{2}{*}{37} & Unidentified Z & 17 & 300 & 4.7 & 5 & 88 & 0.6 & 2 & 35 & 0.6 & 1 & 18 & 0.1 \\
\hline & & 359 & 6328 & $100 \%$ & 898 & 15822 & $100 \%$ & 311 & 5481 & $100 \%$ & 1537 & 27087 & $100 \%$ \\
\hline
\end{tabular}

$\mathrm{s} / \mathrm{cm}^{2}=$ seedlings $/ \mathrm{cm}^{2} ; \mathrm{s} / \mathrm{m}^{2}=$ seeds $/ \mathrm{m}^{2} ; \% \mathrm{c} . \mathrm{s}=\%$ contribution of each species

corymbosa had the highest seedling density of 276 seedlings ( 4863 seeds $/ \mathrm{m}^{2}$ ) or $30.7 \%$ of the seed density of the seed bank (Tab. 2). Tithonia diversifolia seedlings also featured prominently in the seed bank with 193 seedlings (3401 seeds $\left./ \mathrm{m}^{2}\right)$ or $21.4 \%$ of the seed bank density. Species such as Ageratum conyzoides, Euphorbia heterophylla and Physalis anguculata had one seedling (18seeds/m) each, representing $0.1 \%$ of the seed bank, while other species had intermediate values.

In the study site no. 2 and in the dry season sampling, 1537 seedling (27087seed $/ \mathrm{m}$ ) emerged (Tab. 2). A total of 22 species emerged consisting of only one woody species: Trema orientalis, as well as two unidentified species. Bracharia deflexa recorded the highest seedling density 
Tab. 3. Comparison of species composition and Similarity indices (based on Sorenson index) between the seedbank and the standing vegetation of the two study sites in dry and rainy seasons.

\begin{tabular}{|c|c|c|c|c|c|c|c|c|c|c|}
\hline & $\begin{array}{c}\text { No of } \\
\text { species } \\
\text { in the } \\
\text { standing } \\
\text { vegetation } \\
(\mathrm{SV})\end{array}$ & $\begin{array}{c}\text { No of } \\
\text { species in } \\
\text { Seedbank } \\
\text { (SB) }\end{array}$ & $\begin{array}{l}\text { Species } \\
\text { common } \\
\text { to } S V \text { and } \\
\text { SB }(C S)\end{array}$ & $\begin{array}{l}\text { Sorenson } \\
\text { Index of } \\
\text { similarity } \\
\text { between } \\
\text { SV and SB }\end{array}$ & $\begin{array}{c}\text { Sorenson } \\
\text { Index of } \\
\text { similarity } \\
\text { of SB of dry } \\
\text { and Raining } \\
\text { seasons }\end{array}$ & $\begin{array}{c}\text { No of } \\
\text { species } \\
\text { in the } \\
\text { standing } \\
\text { vegetation } \\
(\mathrm{SV})\end{array}$ & $\begin{array}{c}\text { No of } \\
\text { species in } \\
\text { Seedbank } \\
\text { (SB) }\end{array}$ & $\begin{array}{l}\text { Species } \\
\text { common } \\
\text { to SV } \\
\text { and SB } \\
\text { (CS) }\end{array}$ & $\begin{array}{l}\text { Sorenson } \\
\text { Index of } \\
\text { similarity } \\
\text { between } \\
\text { SV and SB }\end{array}$ & $\begin{array}{c}\text { Sorenson } \\
\text { Index of } \\
\text { similarity } \\
\text { of SB of } \\
\text { dry and } \\
\text { Raining } \\
\text { seasons }\end{array}$ \\
\hline $\begin{array}{c}\text { Dry } \\
\text { season }\end{array}$ & 23 & 27 & 13 & 48.1 & 72.4 & 17 & 22 & 8 & 34.8 & 61.9 \\
\hline $\begin{array}{c}\text { Raining } \\
\text { season }\end{array}$ & 23 & 26 & 12 & 44.0 & 72.4 & 17 & 19 & 5 & 26.3 & 61.9 \\
\hline
\end{tabular}

of 429 (7559 seed/m) or $27.9 \%$; it closely followed by Chromolaena odorata with 388 seedlings (6837 seeds $/ \mathrm{m})$ or $25.2 \%$ of the seed bank density, while five species: $\mathrm{Cer}$ atopteris cornuta, Ipomoea involucrata, Larpotea aestuans, Trema orientalis and one of the unidentified species had the least seedlings emergence density of one seedling (18 seeds $/ \mathrm{m}$ ). Tithonia diversifolia also had a seedling emergence density of 25 seedlings ( 441 seeds $/ \mathrm{m}$ ) or $1.6 \%$ of the seedbank density of the study site.

In the rainy season sampling a total of 311 seedlings (5481 seeds/m) emerged in the study site (Tab. 2) consisting of 19 species, two of which were unidentified. One woody species (Trema orientalis) emerged in this soil sample. Bracharia deflexa had the highest seedling density of 138 or 2432 seeds $/ \mathrm{m}$, representing $44.4 \%$ of the total density of the seed bank. Chromolaena odorata recorded the second highest seedling density with 42 seedlings ( 740 seeds $/ \mathrm{m}$ ) or $13.5 \%$ of the seed bank density. Tithonia diversifolia contributed with 24 seedlings ( $423 \mathrm{seeds} / \mathrm{m}$ ) or $7.7 \%$ of the seed bank density. However, six (6) species: Ageratum conyzoides, Euphorbia hirta, Laportea aestuans, Physalis anguculata, Securinega virosa and Sida veronicifolia had the least seedling density of one (01) or 18 seeds $/ \mathrm{m}$ each emerged from the seedbank, while the other species had intermediate values.

The monthly seedlings emergence density in the dry season soil sample revealed that site 2 (Ife-Ilesa single lane) consistently had higher values than site 1 (Ife-Ibadan dual carriage way), but this diference is not significant (Fig.1). In the rainy season the same trend was observed (Fig.2). Comparison of seasonal seedlings emergence in the two study sites revealed that the soil sample of dry season had significantly $(\mathrm{P}=0.05)$ higher number of emerged species in both study sites than that of the rainy seasons sample (see Tab. 2).

\section{Seedbank and standing vegetation}

The comparison of the species composition of seedbank and the standing vegetation revealed that in the study site 1 in the dry season samples, 13 species in the seedbank had representatives also in the standing vegeta- tion (41.9\%) (Tab. 3). The species common to both the seedbank and the standing vegetation are: Andropogon gayanus, Aspilia helianthus, Bracharia deflexa, Chromolaena odorata, Desmodium scorparius, Eupborbia heterophylla, Euphorbia hirta, Mimosa pudica, Phyllantus amarus, Spigella anthelmia, Talinum triangulare and Trianthema portulacastrum, with Tithonia diversifolia being the dominant species. However, for the rainy season sample in the study site 1, apart from Tithonia diversifolia, eleven (11) other species (40.7\%) were represented in both standing vegetation and the seedbank, and these are: Andropogon gayanus, Bracharia deflexa, Chromolaena odorata, Euphorbia heterophylla, Euphorbia hirta, Mimosa pudica, Phyllanthus amarus, Spigella anthelmia, Talinum triangulare, Trema orientalis and Urena lobata.

In the study site 2 , in the dry season samples, eight (8) out of the 23 species (34.8\%) that emerged from the seedbank had representatives in the standing vegetation, apart from Tithonia rotundifolia which was the dominant species. These species are: Andropogon gayanus, Bracharia deflexa, Desmodium scorparius, Ipomoea involucrata, Phyllantus amarus, Spigella anthelmia and Trema orientalis. 19 species emerged from the seedbank of study site 2 in the rainy season and only five (5) species (26.3\%) were represented in the standing vegetation; these species are: Andropogon gayanus, Bracharia deflexa, Phyllantus amarus, Spigella anthelma, Talinum triangulare and Trema orientalis.

Comparison of the species composition of the seedbank (SB) and the standing vegetation (SV) of the two study sites within seasons using Sorenson index of similarity (1948) (Tab. 3) reveals that the level of similarity was generally low; it ranges from $26.3 \%$ in the rainy season for site 2 to $48.1 \%$ in the dry season for site 1 . This result indicates that many of the species emerged from seedbank were not represented in the standing vegetation. Furthermore, the species composition of the seedbank of each study site for the two seasons was subjected to similarity analysis (Sorenson 1948) and the results reveals a high level of similarity, $72.4 \%$ for Site 1 and $61.9 \%$ for Site 2 (Tab. 3). 
Tab. 4. Seedlings Emergence in relation to the extent of the fallowland in the study site 2 in both seasons

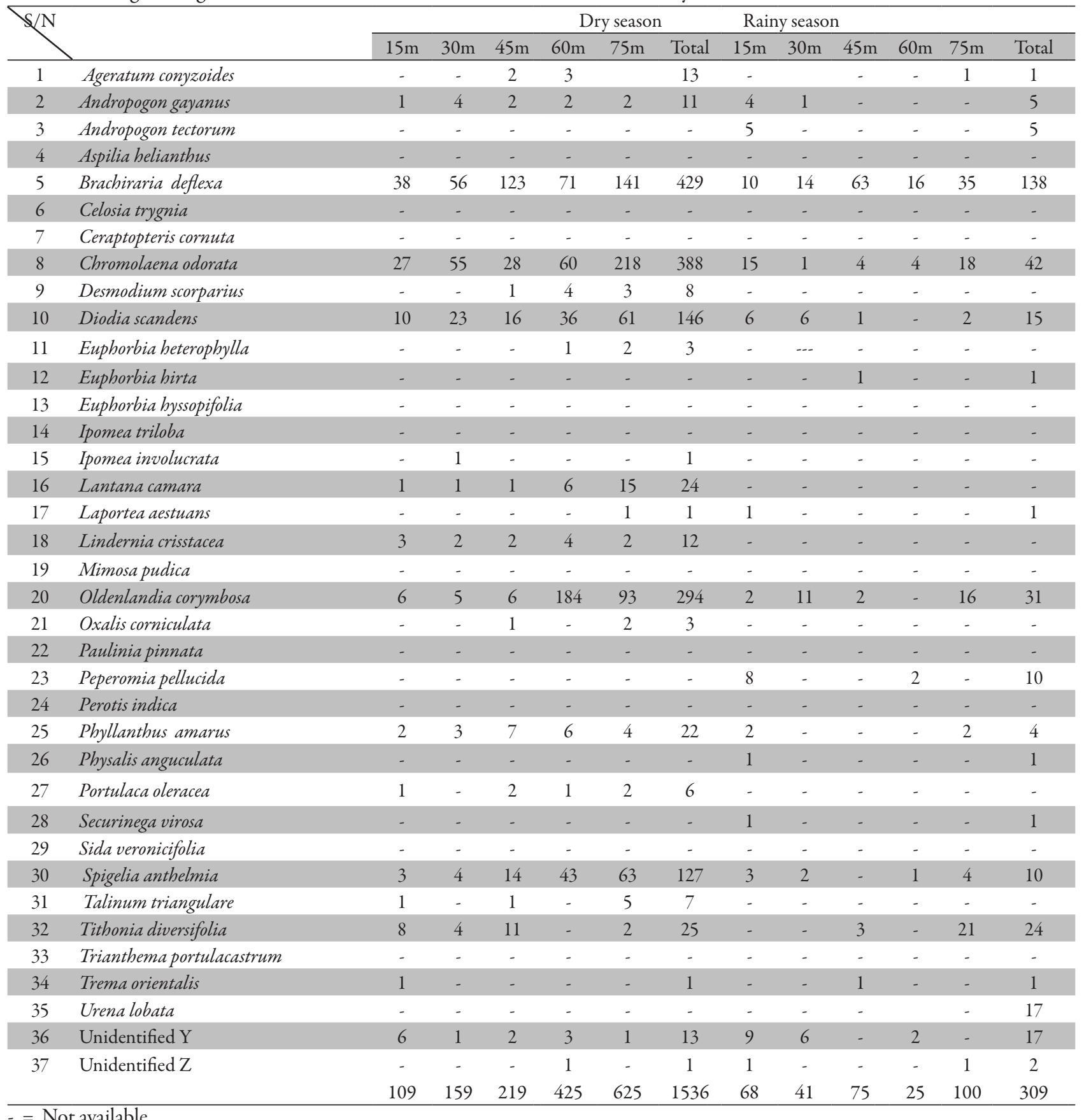

Seedling emergence in relation to extent of the fallowland

The results of the seedling emergence in the 2 seasons and across the five distances show that for site 1 (Ife-Ibadan), the least and the highest seedling density was recorded in the $15 \mathrm{~m}$ and $75 \mathrm{~m}$ respectively inward, away from the main road, during the rainy season and the dry season (Tab. 4). Also for site 2 (Ife-Ilesa) the least and the highest seedling emergence came from $15 \mathrm{~m}$ and $75 \mathrm{~m}$ distance respectively, during the dry season, but the least and highest seedling emergence was observed in the $60 \mathrm{~m}$ and
$75 \mathrm{~m}$ distance respectively during the rainy season (Tab. 5). The total seedling emergence for each distance and for each site was pooled together and were subjected to 2 way ANOVA, it shows a significant difference $(\mathrm{P}=0.01)$ in the seedling emergence density across the various distances. The seedling densities of the two sites were also subjected to students' T-test. The results shows no significance change in seedling density between the two sites. 
Tab. 5. Seedlings Emergence in relation to the extent of the fallowland in the study site 2 in both seasons

\begin{tabular}{|c|c|c|c|c|c|c|c|c|c|c|c|c|c|}
\hline \multirow{2}{*}{$S / N$} & & \multicolumn{6}{|c|}{ Dry season } & \multicolumn{4}{|c|}{ Rainy season } & \multirow[b]{2}{*}{$75 \mathrm{~m}$} & \multirow[b]{2}{*}{ Total } \\
\hline & & $15 \mathrm{~m}$ & $30 \mathrm{~m}$ & $45 \mathrm{~m}$ & $60 \mathrm{~m}$ & $75 \mathrm{~m}$ & Total & $15 \mathrm{~m}$ & $30 \mathrm{~m}$ & $45 \mathrm{~m}$ & $60 \mathrm{~m}$ & & \\
\hline 1 & Ageratum conyzoides & - & - & 2 & 3 & & 13 & - & & - & - & 1 & 1 \\
\hline 2 & Andropogon gayanus & 1 & 4 & 2 & 2 & 2 & 11 & 4 & 1 & - & - & - & 5 \\
\hline 3 & Andropogon tectorum & - & - & - & - & - & - & 5 & - & - & - & - & 5 \\
\hline 4 & Aspilia belianthus & - & - & - & - & - & - & - & - & - & - & - & - \\
\hline 5 & Brachiraria deflexa & 38 & 56 & 123 & 71 & 141 & 429 & 10 & 14 & 63 & 16 & 35 & 138 \\
\hline 6 & Celosia trygnia & - & - & - & - & - & - & - & - & - & - & - & - \\
\hline 7 & Ceraptopteris cornuta & - & - & - & - & - & - & - & - & - & - & - & - \\
\hline 8 & Chromolaena odorata & 27 & 55 & 28 & 60 & 218 & 388 & 15 & 1 & 4 & 4 & 18 & 42 \\
\hline 9 & Desmodium scorparius & - & - & 1 & 4 & 3 & 8 & - & - & - & - & - & - \\
\hline 10 & Diodia scandens & 10 & 23 & 16 & 36 & 61 & 146 & 6 & 6 & 1 & - & 2 & 15 \\
\hline 11 & Euphorbia heterophylla & - & - & - & 1 & 2 & 3 & - & -.- & - & - & - & - \\
\hline 12 & Euphorbia hirta & - & - & - & - & - & - & - & - & 1 & - & - & 1 \\
\hline 13 & Euphorbia byssopifolia & - & - & - & - & - & - & - & - & - & - & - & - \\
\hline 14 & Ipomea triloba & - & - & - & - & - & - & - & - & - & - & - & - \\
\hline 15 & Ipomea involucrata & - & 1 & - & - & - & 1 & - & - & - & - & - & - \\
\hline 16 & Lantana camara & 1 & 1 & 1 & 6 & 15 & 24 & - & - & - & - & - & - \\
\hline 17 & Laportea aestuans & - & - & - & - & 1 & 1 & 1 & - & - & - & - & 1 \\
\hline 18 & Lindernia crisstacea & 3 & 2 & 2 & 4 & 2 & 12 & - & - & - & - & - & - \\
\hline 19 & Mimosa pudica & - & - & - & - & - & - & - & - & - & - & - & - \\
\hline 20 & Oldenlandia corymbosa & 6 & 5 & 6 & 184 & 93 & 294 & 2 & 11 & 2 & - & 16 & 31 \\
\hline 21 & Oxalis corniculata & - & - & 1 & - & 2 & 3 & - & - & - & - & - & - \\
\hline 22 & Paulinia pinnata & - & - & - & - & - & - & - & - & - & - & - & - \\
\hline 23 & Peperomia pellucida & - & - & - & - & - & - & 8 & - & - & 2 & - & 10 \\
\hline 24 & Perotis indica & - & - & - & - & - & - & - & - & - & - & - & - \\
\hline 25 & Phyllanthus amarus & 2 & 3 & 7 & 6 & 4 & 22 & 2 & - & - & - & 2 & 4 \\
\hline 26 & Physalis anguculata & - & - & - & - & - & - & 1 & - & - & - & - & 1 \\
\hline 27 & Portulaca oleracea & 1 & - & 2 & 1 & 2 & 6 & - & - & - & - & - & - \\
\hline 28 & Securinega virosa & - & - & - & - & - & - & 1 & - & - & - & - & 1 \\
\hline 29 & Sida veronicifolia & - & - & - & - & - & - & - & - & - & - & - & - \\
\hline 30 & Spigelia anthelmia & 3 & 4 & 14 & 43 & 63 & 127 & 3 & 2 & - & 1 & 4 & 10 \\
\hline 31 & Talinum triangulare & 1 & - & 1 & - & 5 & 7 & - & - & - & - & - & - \\
\hline 32 & Tithonia diversifolia & 8 & 4 & 11 & - & 2 & 25 & - & - & 3 & - & 21 & 24 \\
\hline 33 & Trianthema portulacastrum & - & - & - & - & - & - & - & - & - & - & - & - \\
\hline 34 & Trema orientalis & 1 & - & - & - & - & 1 & - & - & 1 & - & - & 1 \\
\hline 35 & Urena lobata & - & - & - & - & - & - & - & - & - & & - & 17 \\
\hline 36 & Unidentified Y & 6 & 1 & 2 & 3 & 1 & 13 & 9 & 6 & - & 2 & - & 17 \\
\hline \multirow[t]{2}{*}{37} & Unidentified Z & - & - & - & 1 & - & 1 & 1 & - & - & - & 1 & 2 \\
\hline & & 109 & 159 & 219 & 425 & 625 & 1536 & 68 & 41 & 75 & 25 & 100 & 309 \\
\hline
\end{tabular}

- = Not available

\section{Discussion}

The low level of similarity observed in the standing vegetation of the two study sites using the similarity analysis (Sorenson, 1948) may be a reflection of the difference in species composition of the sites. This observation agrees with the report of Chandrashekara and Ramakrishna (1993) saying that the level of disturbance and succession ages of forest have effects on species composition. The presence of few woody species, most of which are secondary regrowth forest species, also indicates that the sites have been subjected to recent anthropogenic disturbances. The road construction activities has led to the destruction of the existing forest cover and the consequent invasion of the sites by secondary succession species and herbaceous species respectively. Hall and Okali (1979) have observed that the presence or dominance of early succession species is an indication of disturbance. Furthermore, the general dominance of the seedbank of the two study sites by her- 


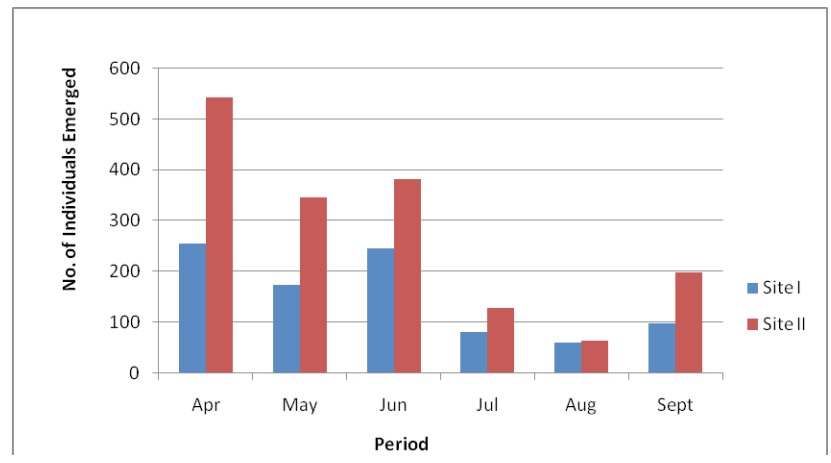

Fig. 1. Monthly seedlings emergence densities in the dry season in Sites I and Sites II

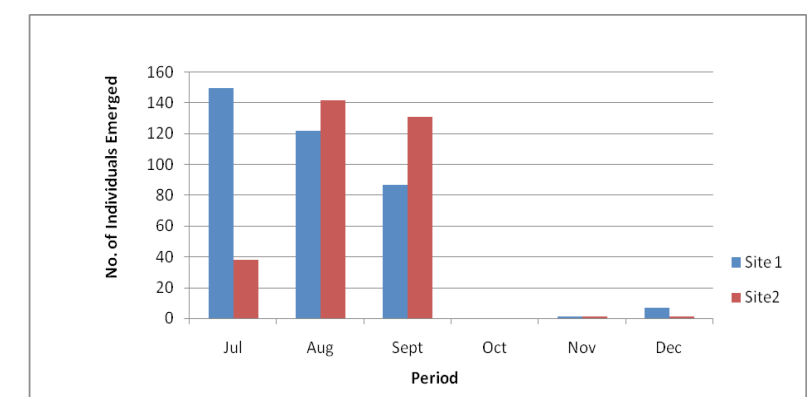

Fig. 1. Monthly seedlings emergence densities in the rainy season in Sites I and Sites II

baceous species is in agreement with the reports of many workers (Oke, et al, 2006, Oladipo and Oke 2007).

The dominance of the soil seedbank by the seedlings of Tithonia diversifolia in site 1 as against site 2 is a reflection of the extent of human disturbance on both sites. Site 1 which is on a dual carriage road has recorded much more construction activities, leading to more extensive open waste land in recent time than site 2 (a single lane) and consequently site 1 is more open to invasion by $T i$ thonia diversifolia which Adebowale and Olorode (2005) described as having a wider spread across the ecological zones of Nigeria. Muoghalu and Chuba (2005) have also posited that Tithonia diversifolia species are plants of open sunny habitats. In agreement with Samuel et al. (2005) the spread of invasive Tithonia diversifolia in our local ecosystem, leading to the replacement of native species/natural secondary fallow lands, can potentially also account the reduced number of seedlings of other species. The high rate of invasion by Tithonia species coupled with ease to colonize suitable open areas (like site 1) thus minimizing competition from other nearby plant species (Adebowale and Olorode, 2005); also growth rate is said to be remarkably fast, as well as forming closely packed populations that tend to choke out 'timid' competitors.

A general lack of correspondence has also been reported for this study between the standing vegetation and the seedbank. This observation is almost a general trend in most soil seedbank studies and has been reported by other workers (Thompson and Grime, 1979; Staaf et al., 1987). Very few of the total species that emerged as seedlings in the seedbank were represented in the standing vegetation. Similarly, Oke et al. (2006) reported a large discrepancy between soil seedbank and standing vegetation. This phenomenon is reflected in this study and can be attributed to the fact that only few species are able to compete with Tithonia diversifolia in its domain, where it is dominant and the possibility fort germination requirements of these other/native species may not be fulfilled.

The seedbank density (5481-29615 seeds $\left./ \mathrm{m}^{2}\right)$ reported for these Tithonia diversifolia dominated sites is comparable to the figures given by other workers for similar disturbed environments, for example Oke et. al (2006) (6274-21872 seeds $\left./ \mathrm{m}^{2}\right)$, Oladipo and Oke (2007) $\left(14115-21420\right.$ seeds $\left./ \mathrm{m}^{2}\right)$. However, the threat that the preponderance of Tithonia species posed to local flora, its reported production of phytotoxins or the allelopathic, that influence the neighbouring plant species (Ayeni et al., 1997), as well as its seed abundance in the seedbank has been observed as a factor that stabilizes Tithonia as a mono specific stand, wherever it is found growing (Muoghalu and Chuba, 2005). This is possibly because it is capable of suppressing other species by outgrowing them (as tall as $5 \mathrm{~m}$ ), as well as the production of chemicals that inhibit the physiology of neighboring species. The presence of Trema orientalis as the only woody species that emerged from the seedbank can be explained by the observation of Samuel et al. (2005) who have observed that invasive species pose a serious threat to native tree species, because of the inhibiting effect of the extracts of the invasive species used, over the native tree seedlings. The effects of allelopathic / phytotoxic influences of species like Tithonia may have important consequences for forest community composition (biodiversity) and succession over time (Samuel et al, 2005). Similarly, allelopathic interactions between plants have been implicated in the patterning of vegetation and weed growth in agricultural systems (Baruah and Sarma 1994). The increase in seedling density during the dry season could be ascribed to the fact that most seeds in the soil seedbank met favourable enviromental conditions to enhance their germination at this period, because favorable weather is a critical factor that determines the fate of seeds stored in the seedbank, whether to germinate or remain dormant. The increase in seedling emergence inwardly away from the road sides in both study plots is an indication that Tithonia diversifolia, which is an aggresive invasive plant, supresses the presence of other native species by outgrowing them, at distances close to the main road, where Tithonia spp density is higher. Hence, many other species seedlings were encountered at distaces far away inwards from the main road, where the influence of Tithonia was less. Akobundu and Agyakwa (1987) and Lordbanju (1991) reported similar report, that $T$. diversifolia was found to be commonly associated with road sides, 
36

open and disturbed habitats, and being absent from areas of mature plant establishments. The appearance and dominance of Chromolaena odorata (another early colonisers of waste lands) inwardly at distances more than $45 \mathrm{~m}$ is an indication that they are yet to be displaced by this invasive $T$. diversifolia at those distances. Overall, results suggest that the number of individuals and species that emerge from the soil seedbank may be due to the negative impact of $T$. diversifolia on other plant species, and by their ability to produce abundance of seeds, that may have some cases a long life in the soil seedbank in the study environment.

\section{References}

Adebowale, A. and Olorode, O. (2005) An overview of the invasive potential of Tithonia species (Asteraceae) in Nigeria. Science Focus, 10(3): 65-69

Akobundu, I. O. and Agyakwa, C. W. (1987): A Handbook of West African Weeds. A publication of International Institute of Tropical Agriculture, Oyo Road, Ibadan, Nigeria. 521pp

Ayeni, A. O. Lordbanjou. O. T. and Majek, B. A. (1997): Tithonia diversifolia (Mexican sunflower) in South- western Nigeria: Occurrence and growth habit. Weed Research, 37(6): 443-449.

Baruah, N. C. and Sarma, J. C. (1994): Germination and growth inhibitory sesquiterpene lactones and a flavone from Tithonia diversifolia. Phytochemistry 36(1):29-36

Chandrashekara, U. M. and P. S. Ramakrishnan (1993). Germinable Soil Seed bank dynamics during gap phase of a humid tropical forest in the Western Ghats of Keralla, India. Journal of Tropical Ecology, 9: 455-467.

Hall, J. B and D. U. U. Okali (1979). A structural and floristic analysis of woody fallow vegetation near Ibadan, Nigeria. Nigerian Journal of Ecology, 67: 321-346

Howard, M. R and A. E. Hartemink (2000). Soil Seed bank and Growth rates of an invasive species, Piper aduncum in the low land of Papua New Guinea. Journal of Tropical Ecology, 16: 243-251.

Hutchinson, J. and J. M. Dalziel (1954-72). Flora of West Tropical Africa (2nd Edition by R.W J Keay and F. N Hepper) Crown Agents for overseas Government, London.

Lordbanju, O. T. (1991). Studies on Mexican sunflower (Tithonia diversifolia (hemsl.). A. Gray in Southwestern Nigeria. Unpublished M.Sc. Dissertation of the University of Ibadan, Ibadan.

Lorence, D. H. and R. W. Suesman (1986). Exotic species invasion into Mauritius wet forest remnants. Journal of Tropical Ecology, 2:137- 162.

Moughalu, J. I. and D. K. Chuba (2005). Seed Germination and Reproductive strategies of Tithonia diversifolia (Hemsl) and Tithonia rotundifolia (P.M Blake). Applied Ecology and Environmental Research. 3(1):39 - 46.

Oke, S. O. and A. O. Isichei (1997). Floristic Composition and Structure of the fallow vegetation in Ile- Ife Area of South Western Nigeria. Nigerian Journal of Botany, 10:37-50.

Oke, S. O., O. T. Oladipo and A. O. Isichei (2006). Seedbank Dynamics and Regeneration in a secondary lowland Rainforest in Nigeria. International Journal of Botany, 2(4): 363-371.

Oladipo, O. T. and S. O. Oke (2007). Seed bank Dynamics, Seedling Emergence and Survival of Herbaceous species in successional Plots in Ile Ife, South western Nigeria. Research Journal of Botany, 2(2): 76-85

Pagad S. and M. Browne (2008) Invasive Species Drive Biodiversity Loss. Worldwatch Institute. http://www. worldwatch.org/node/5473 [Accessed 13th April, 2009]

Raghubanshi, A. S, L. C. Rai, J. P. Gaur and J. S. Singh (2005). Invasive alien species and biodiversity in India. Current Science, 88(4):539-540

Samuel, O. P., A. R. Jennifer and C. Keith (2005). Invasive Plants can Inhibit Native Tree Seedlings: Testing Potential allelopathic Mechanisms: Plant Ecology 18 :153-165)

Staaf, H., M. Johnson and L. G. Olsen (1987). Buried germinable seeds in mature beach forests with different herbaceous Vegetation and soil types, Holaretic Ecology 10:268-277.

Smyth, A. J and F. R. Montgomery (1962). Soil and Land use in central Western Nigeria. The Government of Western Nigeria, Ibadan.

Sorenson, T. (1948). A method of establishing groups of equal amplitude in a Plant society based on similarity of species content. K. Danske Vidensk Selsk 5: 1-34

Thompson, K. and J. P. Grime (1979). Seasonal Variation in the seedbank of herbaceous species in ten contrastinghabitat. Journal of Ecology 67:893- 921. 